\title{
Effect of Trench Isolation on the Self-heating Phenomenon in Advanced Radio Frequency SiGe Heterojunction Bipolar Transistor
}

\author{
N. Kherief ${ }^{1, *}$, S. Latreche ${ }^{1}$, M. Lakhdara ${ }^{1}$, A. Boulgheb ${ }^{1}$, C. Gontrand ${ }^{2}$ \\ ${ }^{1}$ Laboratoire Hyper fréquences et Semiconducteurs - LHS. Département d'électronique, \\ Université des Frères Mentouri Constantine 1, Algerie \\ ${ }^{2}$ Institute of Nanotechnology of Lyon, University of Lyon 1, Lyon, France
}

(Received 15 August 2020; revised manuscript received 15 February 2021; published online 25 February 2021)

\begin{abstract}
This work aims to determine the effect of the trench isolation on the self-heating and electrical performances of SiGe heterojunction bipolar transistor (HBT), the considered structure corresponds to BiC MOS7G $0.25 \mu \mathrm{m}$ technology. Advanced SiGe technologies are essentially achieved with downscaling of the device dimensions and developing its architecture to improve the radio frequency capacity of the device. An interesting development is the introduction of the Shallow and Deep Trench isolation (STI, DTI). These make it possible to reduce considerably the parasitic capacitances and to provide a flat topography after SiGe base epitaxy. The drawback of this is the temperature rise in the device through the self-heating phenomenon. This corresponds to the internal heat dissipation at the transistor junctions. To optimize this effect, we consider the non-isothermal energy balance (NEB) model based on the finite element method and two-dimensional thermal simulations. This model takes into account, particularly, the temperature of the carriers and the overshoot effects which occur in the range of dimensions of the considered devices. Analysis of the effect of trench isolation (shallow and deep trench isolation) on electrical performances of radio frequency SiGe HBT is then carried out considering thermal transfer of the carriers. The software SILVACO-TCAD coupling Athena module (technological process) and Atlas module were used to achieve electro-thermal modeling. We simulated the static gain, the dynamic characteristics $\left(f_{T}, f_{\max }\right)$ and analyzed the heat distribution with and without trench isolation. It is shown that in these modern SiGe HBT structures with trench isolation and for high power regimes, the lattice temperature can greatly exceed $300 \mathrm{~K}$ and so the electrical performances $\beta, f_{T}, f_{\max }$ are significantly degraded. The obtained results agree with some published experimental data.
\end{abstract}

Keywords: NEB model, Radio frequency, Silicon germanium, Self-heating, Trench isolation.

DOI: $10.21272 /$ jnep.13(1).01021

PACS numbers: 85.30.Pq, 71.20.Nr

\section{INTRODUCTION}

Currently and due to improvements in bipolar technologies such as the considered BiCMOS technology, bipolar transistors are vastly used and are predominant in many circuit applications, notably in highspeed performing systems. Communication systems which require an improvement in operating frequencies and current gain as well as reducing noise levels of both semiconductor devices and electronic circuits can be mentioned. Silicon-germanium (SiGe) heterojunction bipolar transistors (HBTs) have established itself as a strong technology and the best positioned candidates to accomplish this demand. Indeed, it permits to have band gap energy lower than that of silicon bipolar transistors $[1,2]$.

The introduction of germanium into the base of SiGe bipolar transistor has certainly improved the electrical properties of the device, but heat dissipation is then observed due to the self-heating phenomenon. So, the characterization and modeling of this effect in bipolar devices remains a major research issue associated with the advancement of HBT technologies [3-5, 14].

Furthermore, in advanced bipolar technologies, deep and shallow trench isolation is used to isolate the active area of the transistor and replace the junction isolation between devices in processes and electrical isolation of adjacent transistors and substrates to reduce parasitic capacity and substrate noise $[3,6,7,15]$. The problem, from a thermal point of view, is that the trench isolation is mainly made of silicon dioxide $\left(\mathrm{SiO}_{2}\right)$ having a very poor thermal conductivity. This induces a restriction of the heat flow and result in larger thermal impedances. The effects of trench isolation are heat studied using the electro-thermal non-isothermal energy balance (NEB) model.

The paper is organized as follows. Section 2 presents the physical models and the structure of SiGe HBT corresponding to BiCMOS7G $0.25 \mu \mathrm{m}$ technology. Section 3 presents the principal results and discussion. Section 4 is the conclusion.

\section{PHYSICAL MODELS AND THE STRUCTURE OF SiGe HBT}

\subsection{The Considered Structure}

The considered structure in this paper is SiGe NPN HBT with a polysilicon emitter doped with $5.10^{20} \mathrm{~cm}^{-3}$ and integrated into the BiCMOS7G $0.25 \mu \mathrm{m}$ technology. The concentration of the contact collector is $10^{20} \mathrm{~cm}^{-3}$

The SiGe base is thin in the order of $30 \mathrm{~nm}$ with doping of $3.4 .10^{18} \mathrm{~cm}^{-3}$ (Fig. 1).

Fig. 2 represents the schematic structure of $\mathrm{SiGe}$ HBT with a different arrangement for the contacts. 


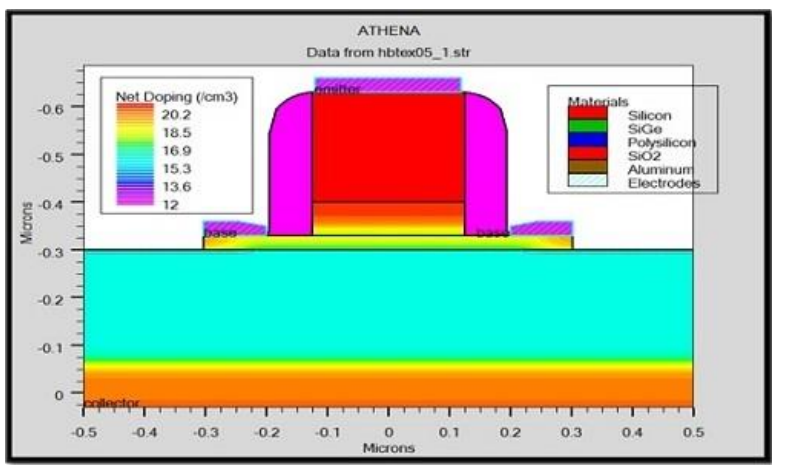

Fig. 1 - SiGe HBT structure considered TCAD software

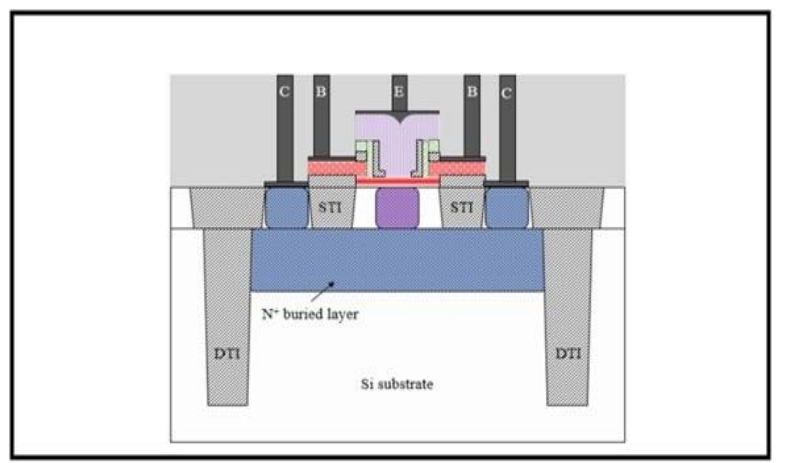

Fig. 2 - Cross-section representing the schematic structure of SiGe HBT with base, emitter and collector arrangement for the contacts [3]

To analyze the electrical performances of the HBT, several physical models can be considered. In a previous study [8], we have compared three electrical models: the DDM model (drift diffusion model), the EB model (energy balance model) and the NEB model (non-isothermal energy balance model).

For nanometric devices, the NEB model is the best for the description of physics devices. Indeed, this model is defined by the basic set of Poisson's equation (1), the electrons and holes continuity equations (2), (3), the electron energy balance equations (4), (5). The lattice heat flow equation (6) permits us to take into account the temperature in the device.

$$
\begin{gathered}
\nabla^{2} \varnothing=\frac{-\mathrm{q}}{\varepsilon_{\mathrm{S}: \mathrm{c}}}\left(\mathrm{p}-\mathrm{n}+\mathrm{N}_{\mathrm{D}}^{+}-\mathrm{N}_{\mathrm{A}}^{-}\right), \\
\frac{\partial \mathrm{n}}{\partial \mathrm{t}}=\mathrm{GR} \mathrm{n}_{\mathrm{n}}+\frac{1}{\mathrm{q}} \frac{d \mathrm{~J}_{\mathrm{n}}}{d \mathrm{x}}, \\
\frac{\partial \mathrm{n}}{\partial \mathrm{t}}=\mathrm{GR} \mathrm{p}_{\mathrm{p}}-\frac{1}{\mathrm{q}} \frac{d \mathrm{~J}_{\mathrm{p}}}{d \mathrm{x}}, \\
\overrightarrow{\mathrm{J}} \equiv-\mathrm{qD} \overrightarrow{\mathrm{V}}_{\mathrm{n}}-\mathrm{q} \mu_{\mathrm{n}} \mathrm{n} \vec{\nabla} \mathrm{V}+\mathrm{qDT} \mathrm{T}_{\mathrm{n}} \vec{\nabla} \mathrm{T}_{\mathrm{n}}, \\
\overrightarrow{\mathrm{J}_{\mathrm{p}}}=-\mathrm{qDp} \overrightarrow{\nabla_{\mathrm{p}}}-\mathrm{q} \mu_{\mathrm{p}} \mathrm{n} \vec{\nabla} \mathrm{V}+\mathrm{qDT} \mathrm{T}_{\mathrm{p}} \vec{\nabla} \mathrm{T}_{\mathrm{p}}, \\
\mathrm{C} \frac{\partial \mathrm{T}_{\mathrm{L}}}{\partial \mathrm{t}}=\nabla\left(\mathrm{K} \nabla \mathrm{T}_{\mathrm{L}}\right)+\mathrm{H},
\end{gathered}
$$

where $\mu_{n}$ and $\mu_{p}$ are the electron and hole mobilities, $D_{n}$ and $D_{p}$ are the thermal diffusivities for electrons and holes, respectively; $T_{n}$ and $T_{p}$ are the temperatures of electrons and holes, respectively, and $T_{L}$ is the lattice temperature.

The developed model links the semiconductor equations to the HTS (heat transfer in solids) ones. It is a coupled system, which consists of a set of partial differential equations (PDEs).

The finite element method is considered to solve the obtained system [10].

The particularity of this model is that it takes into account the temperature of the carriers and the lattice temperature, overshoot effects, and the quasi-ballistic transport $[11,16]$ present in nanometric devices are also considered.

\section{RESULTS AND DISCUSSION}

In the performed TCAD simulation, we have carefully considered the material data. Their properties and physical parameters such as heat conductivity and heat capacity are defined as contained in the SILVACO-TCAD handbook [10].

$$
\mathrm{K}(\mathrm{T})=1 /(\mathrm{TC} . \mathrm{A})+(\mathrm{TC} \cdot \mathrm{B}) * \mathrm{~T}_{\mathrm{L}}+(\mathrm{TC} \cdot \mathrm{C}) * \mathrm{~T}_{\mathrm{L}}{ }^{2} .
$$

The TC.A, TC.B, TC.C parameters are all userspecifiable in the MATERIAL statement.

By solving the lattice heat flow equation (6), we have been able to evaluate the temperature distributions due to the device self-heating.

First, numerical simulations were performed in the DC case. We have obtained the static characteristics of the SiGe HBT considering both the case when trench isolation has been taken into account and the case where the later does not exist. Fig. 3 shows the behavior of the common-emitter current gain $\beta$ versus the emitter-base polarization $V_{\mathrm{BE}}$. We have considered a germanium mole fraction $x=20 \%$ and a collector-base polarization $V_{\mathrm{CE}}=1 \mathrm{~V}$.

So, Fig. 3 shows the static gain $\beta$ for three HBT structures (without trench isolation, with shallow trench isolation (STI) and with shallow and deep trench isolation (STI + DTI)). The maximum gain is about 450 and is obtained at $V_{\mathrm{BE}}=0.7 \mathrm{~V}$ and $V_{\mathrm{CE}}=1 \mathrm{~V}$ when no trench isolation exists. It was observed that the introduction of the later and the temperature effect revealed that the effects of the self-heating seriously decrease static performances, such as static gain, it reaches the value of 400 .

Indeed, it is noteworthy that, for all the investigated structures, the temperature influence on the current gain is observed and is essentially due to the increase in the lattice temperature and also the band gap narrowing. The current gain decreases when the temperature increases. This is due to the spatial band gap discrepancy between the emitter (Si) and the base (SiGe) [11].

This result is consistent with the experimental data related to advanced SiGe technology generations [6]. 


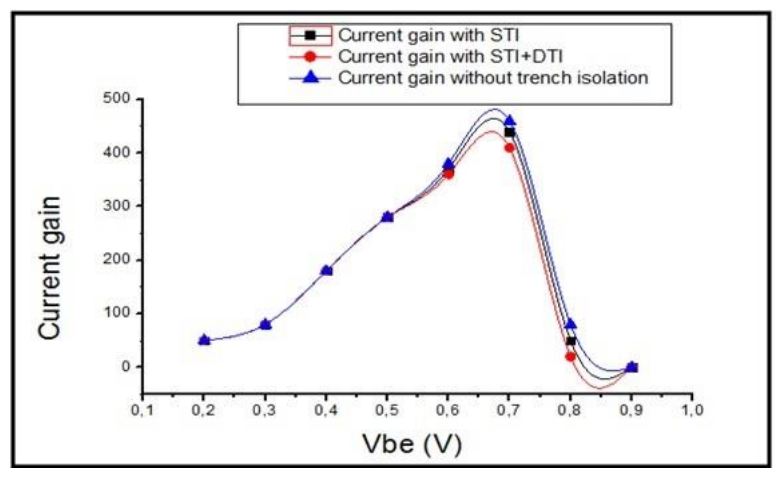

Fig. 3 - Current gain $\beta$ versus $V_{\mathrm{BE}}$ at $V_{\mathrm{CE}}=1 \mathrm{~V}$

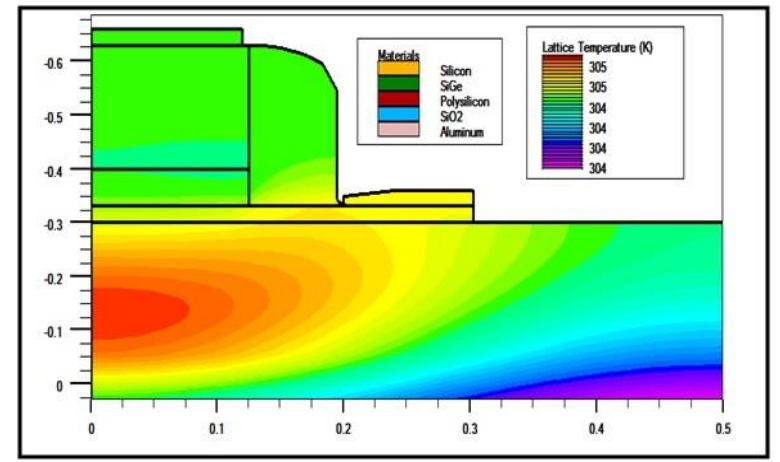

Fig. 4 - Temperature distribution without trench isolation at $V_{\mathrm{CE}}=1 \mathrm{~V}$ and $V_{\mathrm{BE}}=0.8 \mathrm{~V}$

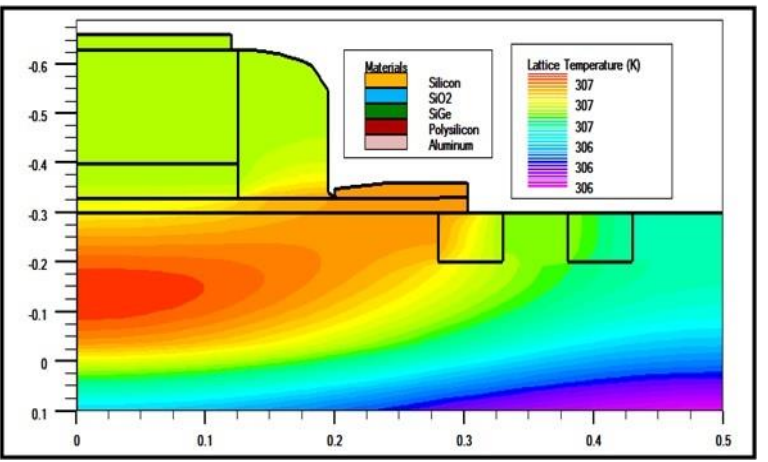

Fig. 5 - Temperature distribution with STI at $V_{\mathrm{CE}}=1 \mathrm{~V}$ and $V_{\mathrm{BE}}=0.8 \mathrm{~V}$

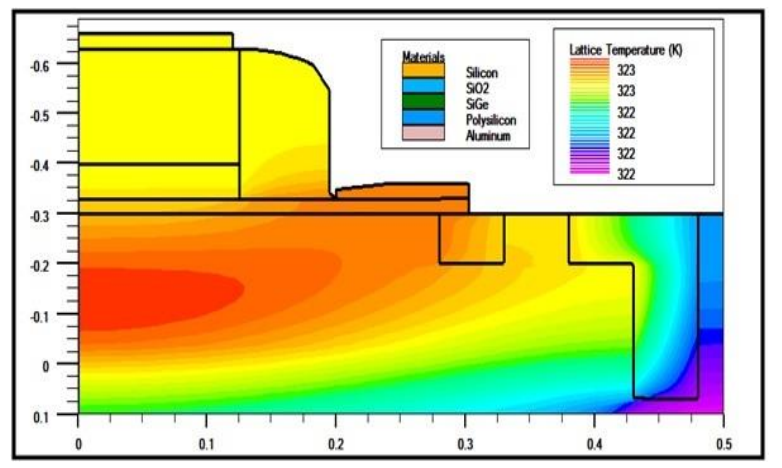

Fig. 6-Temperature distribution with STI at $V_{\mathrm{CE}}=1 \mathrm{~V}$ and $V_{\mathrm{BE}}=0.8 \mathrm{~V}$

The heat flow is no more confined in a reduced silicon volume; it spreads all around the structure, hence depends strongly on the device environment in the case of SiGe HBT without trench isolation (Fig. 4). But with considering trench isolation (STI + DTI), the lateral heat flow is reduced and directed towards the vertical. Due to the poor thermal conductivity of the trench wall, the heat flow from the heat source is mostly confined within the trench-enclosed region before scattering into the substrate and so increasing the temperature of active device (Fig. 5 and Fig. 6).

Special attention is paid to examine the temperature distribution along the depth of the active transistor structure (Fig. 7).

Along the depth of the device, two materials exist: $\mathrm{Si}$ and SiGe. The SiGe base alloy has a lower thermal conductivity $\left(k_{\mathrm{SiGe}}=14 \mathrm{~W} / \mathrm{m} \cdot \mathrm{K}\right.$ for $\left.T=300 \mathrm{~K}\right)$ than that of silicon $(k \mathrm{Si}=150 \mathrm{~W} / \mathrm{m} . \mathrm{K})$. The consequence is that the SiGe base acts as a blockade for heat dissipation in the direction of the emitter. Hence, a high value of the peak temperature $T_{\max }$ and an abrupt drop in the temperature distribution were observed.

Fig. 8 shows the electron temperature distribution when the device is operated at $V_{\mathrm{CE}}=1 \mathrm{~V}$ and $V_{\mathrm{BE}}=0.8 \mathrm{~V}$. The maximum temperature of electrons is about $1600 \mathrm{~K}$.

It can be noted that the maximum temperature of electrons is mainly generated in the collector-base junction when the electric field is greatest and when the lattice temperature is maximum.

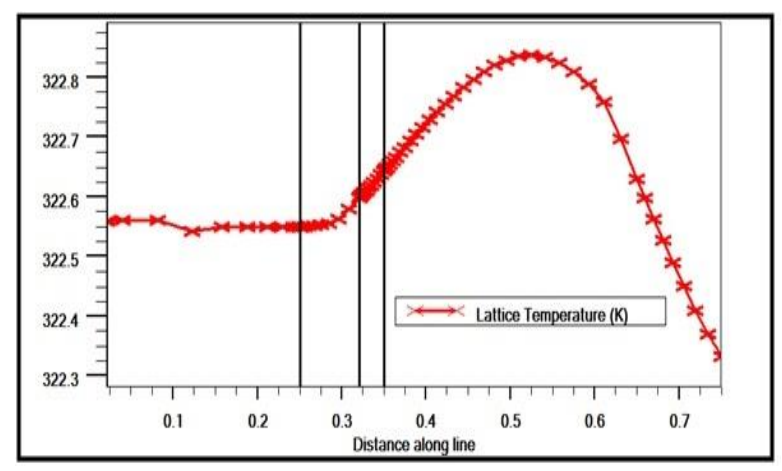

Fig. 7 - Temperature distribution along the transistor internal active region cross-sections $(X=0.0 \mu \mathrm{m})$ for SiGe HBT at $V_{\mathrm{CE}}=1 \mathrm{~V}$ and $V_{\mathrm{BE}}=0.8 \mathrm{~V}$

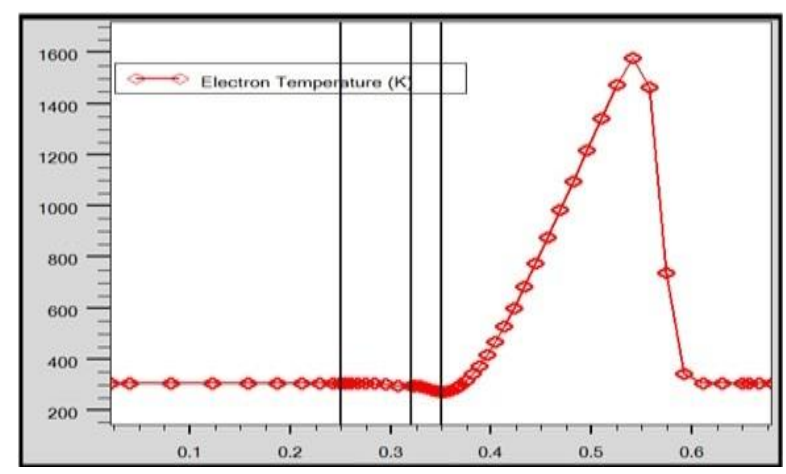

Fig. 8 - Electron temperature distribution along the transistor internal active region cross-sections $(X=0.0 \mu \mathrm{m})$ for $\mathrm{SiGe}$ HBT at $V_{\mathrm{CE}}=1 \mathrm{~V}$ and $V_{\mathrm{BE}}=0.8 \mathrm{~V}$

Regarding the dynamic characteristics, we are interested in the most significant parameters such as the transition frequency $f_{T}$ and the maximum oscillation frequency $f_{\max }$. 


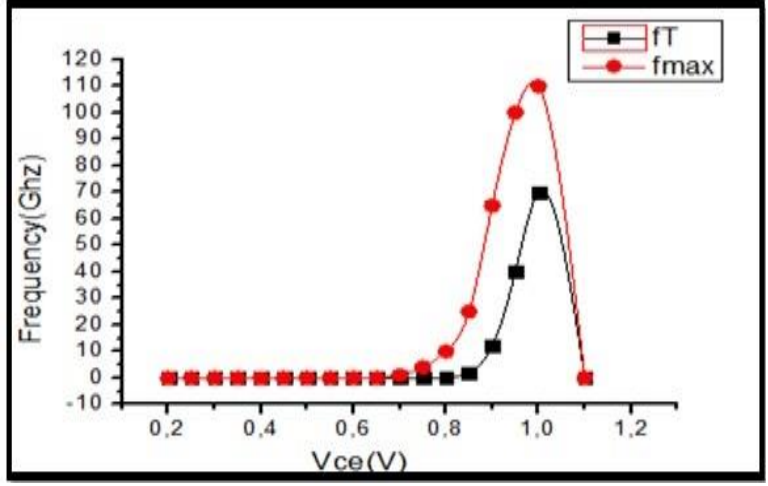

Fig. 9- $f_{T}$ and $f_{\max }$ for SiGe HBT without trench isolation versus $V_{\mathrm{CE}}$

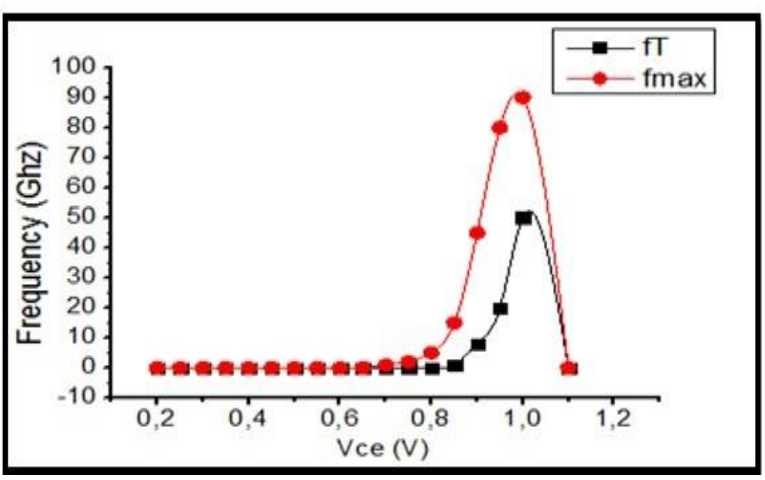

Fig. $10-f_{T}$ and $f_{\max }$ for SiGe HBT with STI and DTI trench isolation versus $V_{\mathrm{CE}}$

So, we have investigated the degree of device selfheating due to the trench isolation presence.

The increase in the peak temperature and the temperature of non-uniformity effects has a real impact on the device radio frequency behavior. Fig. 9 and Fig. 10 show the dynamic performances versus the operating polarization of the considered HBT without trench isolation $\left(f_{T}=70 \mathrm{GHz} ; f_{\max }=110 \mathrm{GHz}\right)$ and with shallow STI and deep DTI trench isolation. These values are favorably compared to those published in [12]

It was observed that the introduction of trench isolation (STI + DTI) decreases the value of the device

\section{REFERENCES}

1. R. Chen, D.Y. Jin, W.R. Zhang, L.F. Wang, B. Guo, H. Chen, L.H. Yin, 14th IEEE International Conference on Solid-State and Integrated Circuit Technology (2018).

2. A.K. Sahoo, S. Fregonese, M. Weib, B. Grand Champ, T. Zimmer, Solid-State Electron. 76, 13 (2012).

3. D. Esposito, R. Frégonese, T. Zimmer, Nanoelectronics: Devices, Circuits and Systems (India: Brajesh Kumar Kaushik: 2018).

4. E. Canderle, Etudes et développement de transistors bipolaires Si/SiGe:C rapides dans un noeud BiCMOS $55 \mathrm{~nm}$ (Université de Lille: 2014).

5. J.D. Gressler, G. NiU, Silicon germanium Heterojunction Bipolar Transistors (Artech House: 2003).

6. A.K. Sahooetal, IEEE T. Electron. Dev. 59 No 10, 2619 (2012).

7. Jce-Sung Rieh, D. Greenberg, Qizhi Liu, et al, IEEE T. Electron. Dev. 52 No 12, 2744 (2005).

8. N. Kherief, S. Latreche, M. Lakhdara, 5th International frequency $\left(f_{T}=50 \mathrm{GHz} ; f_{\max }=90 \mathrm{GHz}\right)$. This is particularly due to the problem of the self-heating phenomenon and, on the other hand, the effect of the substrate capacity CCS.

The substrate capacity decreases with the presence of these isolations. Indeed, both STI and DTI trench isolations are fabricated with $\mathrm{SiO}_{2}$ material which presents a low thermal conductivity $K_{\mathrm{SiO}_{2}}=1.38 \mathrm{~W} / \mathrm{m} \cdot \mathrm{K}$ at $T=300 \mathrm{~K}$.

Table 1 provides a summary of the static characteristics and RF performances at $V_{\mathrm{CE}}=1 \mathrm{~V}, V_{\mathrm{BE}}=0.8 \mathrm{~V}$.

Table 1 - DC and RF performances in different HBT structures

\begin{tabular}{|c|c|c|c|}
\hline HBT structures & $\begin{array}{c}\text { Without } \\
\text { trench } \\
\text { isolation }\end{array}$ & $\begin{array}{c}\text { With } \\
\text { STI }\end{array}$ & $\begin{array}{c}\text { With } \\
\text { STI + DTI }\end{array}$ \\
\hline $\begin{array}{c}\text { Maximum temperature } \\
\text { at } V_{\mathrm{CE}}=1 \mathrm{~V}, V_{\mathrm{BE}}=0.8 \mathrm{~V}\end{array}$ & 305 & 307 & 323 \\
\hline Current gain $\beta$ & 440 & 420 & 400 \\
\hline$f_{T}(\mathrm{GHz})$ & 70 & 60 & 50 \\
\hline$f_{\max }(\mathrm{GHz})$ & 110 & 100 & 90 \\
\hline
\end{tabular}

\section{CONCLUSIONS}

This paper analyzes the effect of trench isolation on the self-heating phenomenon and electrical performances in SiGe NPN heterojunction bipolar transistor (HBT) integrated into a BiCMOS7G $0.25 \mu \mathrm{m}$. Electro-thermal modeling of these trench-isolated SiGe HBTs is proposed.

DC and AC performances are presented. Three issues about trench isolation dependence are studied: current gain, temperature distribution and dynamic performances with and without trench isolation.

The results obtained show that trench isolation has a significant influence on the static gain and heat dissipation. In addition, an important impact on dynamic performances was observed.

The proposed TCAD electro-thermal modeling can be considered as a means for HBT devices improvement in thermal and electrical performances. So, this work provides the basis for self-heating study in RF circuits and, in particular, the existing thermal coupling in these structures.

Conference on Electrical and Electronic Engineering (IEEE Xplore: Istanbul: 2018)

9. Y. Apanovich, E. Lyumiks, B. Polsky, IEEE T. Comput.Aided Design Integr. Circuits Syst. 13, 6 (1994).

10. Atlas, SILVACO-Tcad, International, Santa Clara, (2010).

11. C. Mukherjee, C.K. Maiti, J.B. Appl. Phys. 3 No 1, 16 (2014).

12. F. Blanchet, Analyse et caractérisation des performances en puissance de transistors bipolaires à hétérojonction SiGe:C pour des applications de radio-communications portables (Université de Limoges: Juin: 2007).

13. D.J. Walkey, T.J. Smy, C. Reimer, M. Schroter, H. Tran, Marchesan David, Solid-State Electron. 46, 7 (2002)

14. K. Raleva, D. Vasileska, S.M. Goodnick, M. Nedjalkov, IEEE T. Electron. Dev. 55 No 6, 1306 (2008).

15. A. Peter, SiGe Heterojunction Bipolar Transistors (Wiley: 2003).

16. A.K. Sahoo, S. Fregonese, R. D'Esposito, C. Maneux, T. Zimmer, IEEE T. Electron. Dev. 62 No 1, 232 (2015). 


\title{
Вплив ізоляції канавок на явище самонагрівання у вдосконаленому радіочастотному біполярному транзисторі з гетеропереходом $\mathrm{SiGe}$
}

\author{
N. Kherief ${ }^{1}$, S. Latreche ${ }^{1}$, M. Lakhdara ${ }^{1}$, A. Boulgheb ${ }^{1}$, C. Gontrand ${ }^{2}$ \\ ${ }_{1}$ Laboratoire Hyper fréquences et Semiconducteurs - LHS. Département d'électronique, \\ Université des Frères Mentouri Constantine 1, Algerie \\ 2 Institute of Nanotechnology of Lyon, University of Lyon 1, Lyon, France
}

\begin{abstract}
Робота спрямована на визначення впливу ізолящії канавок на самонагрівання та електричні характеристики біполярного транзистора з гетеропереходом (HBT) SiGe, розглянута структура відповідає 0,25 мкм технології BiCMOS7G. Вдосконалення технології SiGe досягається в основному зменшенням розмірів пристрою та розробкою його архітектури для поліпшення радіочастотної ємності. Цікавою розробкою е впровадження ізоляції мілких та глибоких канавок. Вона дозволяе значно зменшити паразитні емності та забезпечити плоску топографію після епітаксії основи SiGe. Недоліком такого впровадження є підвищення температури в пристрої через явище самонагрівання. Це відповідає внутрішньому тепловиділенню на транзисторних переходах. Для оптимізацї цього ефекту ми розглянемо модель неізотермічного енергетичного балансу (NEB), засновану на методі кінцевих елементів та двовимірному тепловому моделюванні. Ця модель враховує, зокрема, температуру носіїв та надлишкові ефекти, що виникають у діапазоні розмірів розглянутих пристроїв. Потім проводиться аналіз впливу ізоляції канавок (мілких та глибоких) на електричні характеристики радіочастотного HBT SiGe з урахуванням теплового переносу носіїв. Для реалізації електротермічного моделювання використовували програмне забезпечення SILVACO-TCAD, яке поєднує модуль Athena (технологічний процес) та модуль Аtlas. Ми змоделювали статичний коефіцієнт підсилення, динамічні характеристики $\left(f_{T}, f_{\max }\right)$ та проаналізували розподіл тепла з ізоляцією канавок та без неї. Показано, що в сучасних структурах HBT SiGe з ізоляцією канавок та при режимах високої потужності температура решітки може значно перевищувати $300 \mathrm{~K}$, і тому електричні характеристики $\beta, f_{T}, f_{\max }$ значно погіршуються. Отримані результати узгоджуються з деякими опублікованими експериментальними даними.
\end{abstract}

Ключові слова: Модель NEB, Радіочастота, Кремній-германій, Самонагрівання, Ізоляція канавок. 